\title{
MULTIPLE ROLE OF TRANSPORT IN RURAL DEVELOPMENT
}

Ing. Kamil Pícha, Ph.D.

assistant professor

University of South Bohemia

Faculty of Economics

Department of Trade and Tourism

Studentská 13

37005 České Budějovice

Czech Republic

E-mail: kpicha@ef.jcu.cz

Mgr. Vladimír Dvořák

assistant professor

University of South Bohemia

Faculty of Economics

Department of Trade and Tourism

Studentská 13

37005 České Budějovice

Czech Republic

E-mail: dvorak@ef.jcu.cz

The paper was elaborated with the financial support of the research project MSM 6007665806. 


\title{
MULTIPLE ROLE OF TRANSPORT IN RURAL DEVELOPMENT
}

\section{Key words:}

rural development, rural area, transport, tourism, tourist destination, sustainability

\begin{abstract}
:
The paper aims to find different ways of how to consider a potential benefit of transport to the development of rural areas or tourist destinations. The role of transport is quite often underestimated when creating a development strategy in the target area. Numerous papers and discussions show that transport play certain economic and also social role in human existence. Benefits could be found from the point of view of both transport infrastructure and services of public transport.
\end{abstract}




\section{INTRODUCTION}

The rural sector plays an important role in both developed and developing countries. The approach to the perception of this role is obvious from multiple statements of EUrepresentants (FISHER BOEL, M., 2007, FISCHLER, F., 1998).

Rural areas are seen as

- territory producing food and valuable raw materials

- place for rest and recreation

- territory of natural environment and rich variety of eco-systems, landscape producing oxygen (ecological counterpart for increased pollution in urban areas)

- territory perpetuating cultural heritage

Rural areas have, however, to be seen above all as territory where people are living. They are the same people as in cities, urban areas, with similar needs and more and more with similar habits and ways of living.

\section{FACTORS AND PRINCIPLES OF RURAL DEVELOPMENT}

The EU rural development policy is based on four principles (CASTRO, P. de, 2003):

- the multifunctional role of agriculture,

- an integrated multi - sectoral approach to the rural economy aimed at diversifying activities, creating new sources of income and employment and preserving rural heritage,

- flexibility of support to rural development, based on subsidiarity and the promotion of decentralization, regional and local co-operation and partnerships,

- transparency in the development and management of program's, based on simplified and more easily accessible legislation. 
The EU rural development policy for 2007-2013 focuses on three key areas: the agro -food economy, the environment and the broader rural economy and population (COUNCIL DECISION 2006/144/EC).

The main factor of a successful rural development is to maintain inhabitants in rural area and decrease moving people from villages and countries to the towns and cities. This means to provide rural inhabitants by means covering their needs - employment and basic services. In last decades, the countryside faced to a dramatic reduction in farm employment. Hand-inhand with changes in industry related to the market concentration and globalization, the lack of the demand for labor from the part of employer has escalated a critical situation. A large part of countryside is now characterized by strong out-migration, inhabitants' ageing and a slow decline.

According to HEILIG, G.K (2002) the rural development has 5 basic dimensions further including partial factors (Figure 1.):

- Human dimension

- Economic dimension

- Science and technology

- Resources and environment

- Political dimension 
Figure 1. Basic dimension's of the rural development

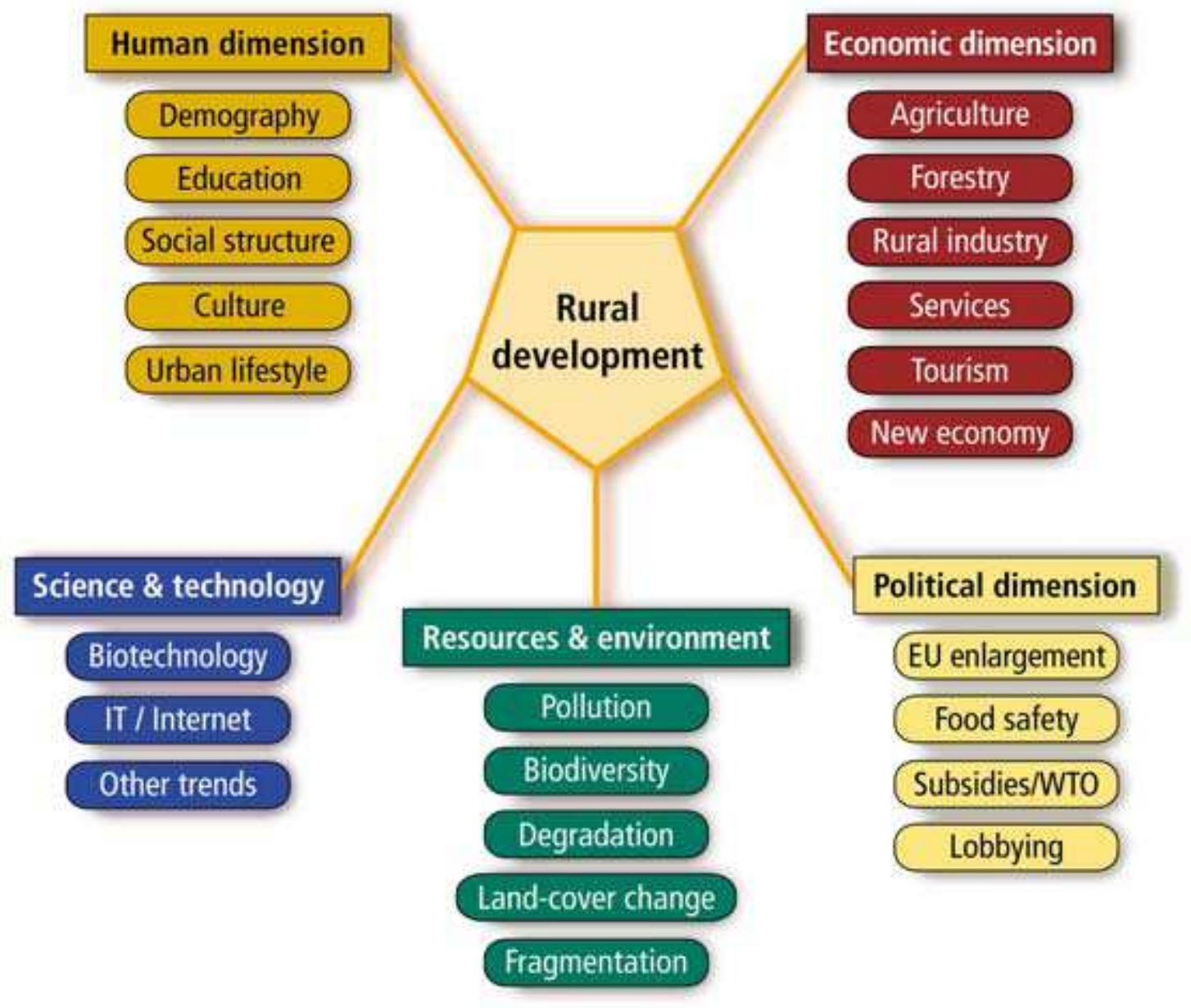

Source: HEILIG, G.K (2002)

\section{PROBLEMS OF TRANSPORT}

Most of cited dimensions and many partial factors are related to the problems of transport. Transport is very often a difficulty to solve when living in countryside or when planning to discover some tourism attractions there. Second part of $20^{\text {th }}$ century lived a reduction of public transport in many rural areas in developed countries. For example, we can take a case of Czech Republic. The total distance of unused railways in the Czech Republic represented in summer 2006 more than $1000 \mathrm{~km}$. (KALA, L. 2006), about 80 percent of which represents railways interconnected villages with more important towns. Other $86 \mathrm{~km}$. of 
railways was abandoned in December 2006. In other cases not only train but also bus relations are reduced.

MADU, I.A. (2007) noticed that "the spatial variation in availability and access to rural infrastructure results in spatial disparities in living standards both within and between regions and localities". Rural areas usually offer only a limited number of jobs. Due to this fact, people living in rural areas quite often have to find job somewhere else and consequently they have to solve the problem of day-to-day traveling to the place of their job. They have to spend time and money for traveling, and therefore their leisure time and purchasing power decrease.

\section{Transport and tourism}

Quite often in the past but also sometimes at present, tourism or leisure time is considered as having low importance for transport, as neglect able part of human mobility. Accordingly to this fact, a low attention was paid and small amount of resources was destined to the development of transport infrastructure of tourist destinations. Leisure or tourist travel has, however increased markedly in last decades. As an example we can cite the case of Germany described by SCHIEFELBUSCH, M. et al. (2007): “About $48 \%$ of passenger transport performance in Germany is caused by leisure activities.” According to PAGE, S.J. (2005), transport provides an essential link between tourism origin and destination areas, and facilitates this way movement of people spending their holiday, business travelers, peoples visiting their families and friends and also those undertaking educational ad health tourism.

DICKINSON J.E., ROBBINS, D. (2008) remark that transport to and within destinations appears marginalized in the tourism literature and there are inherent conflicts involved for tourism. They point out that it is very important to understand, the local tourism transport problem is the result of the combined effect of different groups' competing needs for travel: 
- tourists' journey from home to destination on day of arrival and departure;

- day-visitors' journey from home to destination;

- journeys in the destination area undertaken by tourists and residents for leisure purposes;

- utility journeys undertaken in the destination by visitors and residents such as food shopping.

\section{Transport and sustainability}

The topic of transport and environment or sustainable development is subject to many discussions and also scientific work. The increase of individual transport has escalated quantity of pollutants and also intensified damaging of countryside that suffers, of course by every human activity. Public transport could bring to use right roads right way and also generally to the less of exhalations and less of air pollution. It is a known fact that buses ad trains produce significantly less of emissions per passenger journey than cars. In addition, public transport use only determinate routes while individual transport quite often use undesirable ways and roads, what results in damages for natures and environment. According to BANISTER, D. and BUTTON, K.J. (1993) there is a large underinvestment in public transport but we have to go in discussions beyond this fact and everyday observation.

\section{CONCLUSION}

Transport plays an important role in development of rural areas as a whole. It concerns both social end economic roles. Public transport represents an opportunity to improve the environment or at least to bring for sustainable environment. Transport infrastructure is a significant factor of rural development in different ways - there is a question of supply inhabitants, providing health care, possibility of travelling for job etc. And if there are some 
tourist attractions, transport infrastructure is vital for attracting visitors to the region and particular destinations.

The topic of transport as factor of rural development and development of tourist destination is often underestimated and offer many opportunities for research.

\section{LITERATURE}

Banister, D., Button, K.J. (1993). Transport, the Environment and Sustainable Development. Taylor \& Francis, Inc. 275 p. ISBN 0419178705.

Castro, P. de (2003). The role of Rural Development in the Common Rural Policy. in in The Future of rural policy: from sectoral to place-based policies in rural areas. OECD Publishing, 2003. 248 s. ISBN 9264100830. s. 189-196.

COUNCIL DECISION of 20 February 2006 on Community strategic guidelines for rural development (programming period 2007 to 2013) (2006/144/EC)

Dickinson J.E., Robbins, D. (2008). Representations of tourism transport problems in a rural destination. Tourism Management 29 (2008) ISSN 1110-1121.

Heilig, G. K. (2002). European Rural Development (ERD). Project Description. 4th Revision, April 18, 2002 Laxenburg: International Institute for Applied Systems Analysis (IIASA). 23 s. http://www.iiasa.ac.at/Research/ERD/pdf/erd_pd_8b.pdf

Fischler, F. (1998). Multifunctionailty and identity of rural areas in Europe. Seminar "Por un comercio mundial Compatibile con un espacio rural multifunctional y sostenible" Comunidad Autonóma del País Vasco, 26-28 November 1998

http://www.nekanet.net/congress/conclusiones/pdf/Fishler.pdf

Fisher Boel, M. (2007, April 02). Role of rural areas in tomorrow's Europe. European citizens' Panel Initiative, Committee of the Regions Brussels, 02 April 2007. 
http://europa.eu/rapid/pressReleasesAction.do?reference=SPEECH/07/214\&format=PDF\&ag ed $=1 \&$ language $=$ EN\&guiLanguage $=$ en

Kala, L. (2006, June 30). Cyklostezky na zrušených železnicích. C.O.T. Business. Retrieved June 07, 2009, from http://www.cot.cz/zobrazcl.php?id=6343

Madu, I. A. (2007). Case Study The Underlying Factors of Rural Development Patterns in the Nsukka Region of Southeastern Nigeria. Journal of Rural and Community Development 2(2007). s. 110 - 122. ISSN 1712-8277

Page, S. J. (2005) Transport and Tourism: Global Perspectives. 2nd edition. New York: Pearson Prentice Hall. 450 p. ISBN 0-13-124945-2

Schiefelbusch, M. et al. (2007). Transport and tourism: roadmap to integrated planning developing and assessing integrated travel chains. Journal of Transport Geography 15 (2007) 94-103 